\title{
POSSIBILITIES OF IMPROVING THE PROCESS OF PICKING WAREHOUSE ORDERS ON A SELECTED EXAMPLE
}

\author{
Iwona ŻABIŃSKA ${ }^{1 *}$, Adrian PILLER ${ }^{2}$ \\ ${ }^{1}$ Silesian University of Technology, Faculty of Organization and Management, Zabrze; \\ Iwona.Zabinska@polsl.pl, ORCID: 0000-0002-9368-4311 \\ ${ }^{2}$ Silesian University of Technology, Faculty of Organization and Management, Zabrze; Adrian.Piller@o2.pl \\ * Correspondence author
}

Purpose: The main aim of the article is indicates the possibilities of streamline the public procurement picking process taking place in the selected warehouse.

Design/methodology/approach: Areas requiring corrective action have been identified through the use of the indicator method and Ishikawa diagram. For reorganizing the storage zone, thereby reducing order picking time, $\mathrm{ABC}$ analysis was used.

Findings: The analysis of test results allowed to identify two areas requiring improvement in the picking process: productivity and organization of the storage zone. In order to improve the picking process, it was proposed to reorganize the storage zone.

Originality/value: The article presents a practical value for better logistics processes in warehouse. The analysis of corrective actions areas can also reduce the number of errors when picking the products in warehouse.

Keywords: order picking, warehouse logistics, distribution centre.

Category of the paper: research paper.

\section{Introduction}

Warehouse logistics is designed to ensure the efficient flow of goods, information and documents. Nowadays, it is well developed in various areas of the economy. The distribution of goods is an important element of the logistics chain. Large companies have distribution centres to be able to supply their stores on an on-going basis. In the warehouse, processes such as reception of goods, storage of goods, picking of orders and delivery of goods to stores take place. The picking process is the most time-consuming and labour-intensive warehouse process. Hence, more and more researchers attempt to identify errors in the picking process and identify opportunities to improve this process (Garbacz, Łopuszyński, 2015; Le Duc, 2005; Lorenc, 
Kaczor, 2012; Petersen, Aase, Heiser, 2004; Sabo-Zielonka, Tarczyński, 2014; SzadaBorzyszkowska, Szada-Borzyszkowski, 2017).

\section{Research methodology}

The methodology of research carried out as part of this paper was focused on achieving the goal of improving the picking process in the selected warehouse by shortening the order picking time. Research tools were: Ishikawa diagram, $\mathrm{ABC}$ method and ratio analysis. Data were obtained from the company's internal documentation and from interviews with warehouse employees.

\section{Picking process}

The essence of picking consists in taking stocks from the storage zone to create a set of stocks in accordance with the assortment and quantity specifications for a specific recipient. According to Ratkiewicz A. (2011), completing the order consists in combining unit or collective packaging into loading units formed in accordance with the orders of recipients. Picking can take place in or out of storage (PN-EN 9000:2001). The picking zone is characterized by a large number of manipulations and manual operations. Completion cannot be carried out correctly in the event of a lack of stock in the warehouse. Research conducted in Great Britain has shown that about $63 \%$ of warehouse operational costs are generated by the activities that constitute the picking process. Most time, because about 50\% absorbs the employee's movement, which means that this activity is crucial in improving the entire process. Other activities consuming significant time in processing the picking process are:

- searching for articles and places for these articles (about 19\%),

- taking articles (about 13\%),

- organizing, e.g. label changing (around 9\%) (Drury, 1988; Sabo-Zielonka, Tarczyński, 2014).

\section{Characteristics of the picking process in the analysed warehouse}

Order picking in a regional warehouse takes place simultaneously in several places. These are: 
- low storage zone,

- transit,

- high storage zone.

\subsection{Low storage department}

The tested low storage department has 4740 available addresses (a rack element for which a package with items to be picked is assigned). The construction of the department is shown in Figure 1.

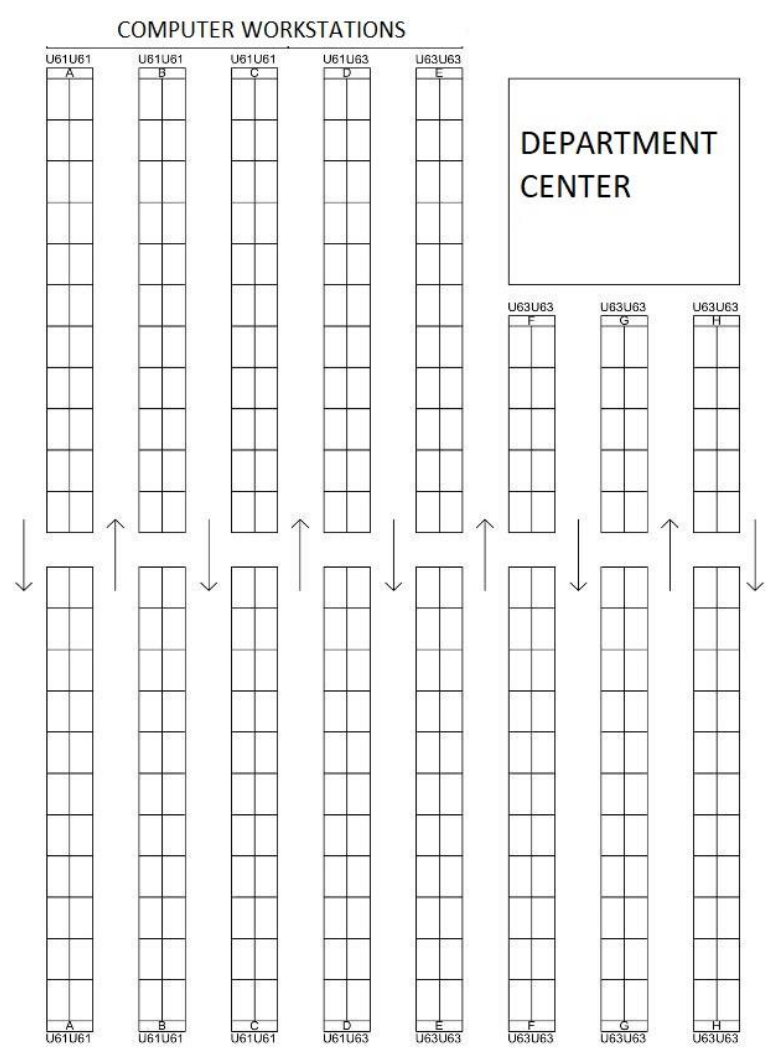

Figure 1. Low storage department - top view. Own study.

From the top view you will notice the so-called Centre Department and shelving. A Centre Department is an office room where employees start work, manage orders, etc. The shelves are divided by the letters of the alphabet from A to $\mathrm{H}$. In the aisles you can move only one way to avoid employee meetings (no space to bypass each other). Figure 1 shows arrows that indicate the direction of employees in a given aisle. The drawing shows the designations of universes (U61 and U63). Employees' task is to search and take articles appearing in the system. Articles are collected in cardboard or plastic boxes. Workers use special hand picking trolleys to move boxes. To move between aisles, the $S$-shape method is used, which consists of moving along a route similar to the letter S. The employee starts at the starting point, visits only those aisles where he takes at least one article. In this method, warehouse workers do not retreat back into the aisles (Figure 2). 


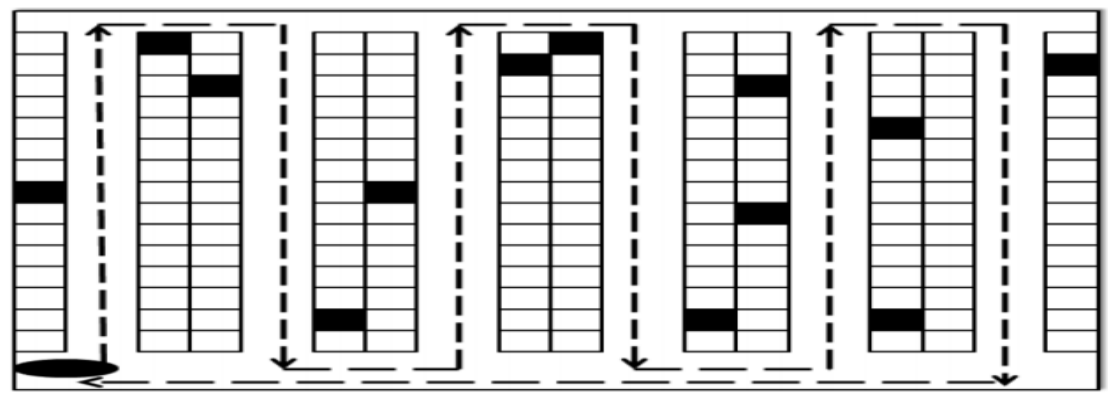

Figure 2. The S-shape method, Sabo-Zielonka A., Tarczyński G. (2014).

The order is carried out simultaneously for one, two, three and even four stores. Orders are collected according to the FIFO (first in first out) principle. When all items from a given order are collected, the employee scans the labels of all items, resulting in receiving colis sticker, it means a sticker containing all the necessary information, such as: number of items, type of carrier, contractor (employee's name), time and date of printing, colis number, city where the package is intended and the store number. Such a parcel is sent by conveyor belt to the UAT zone. Before the UAT zone, the package is checked by the RFID system. In the UAT zone, the conveyor belt is divided into 10 lanes with pallets for individual cities. The conveyor is programmed in such a way that it throws packages out into lanes as intended. The exception are packages with damaged colis stickers. Then the package goes to the last lane intended for the so-called anomalies. These are packages that cannot be sent and require a solution. These packages go back to departments or are sent without flow to the customer, depending on the status of the package. Full pallets should be placed on the foliar, using a scanner to scan all colis stickers in the system, thanks to which a UAT label is obtained. The label on the item pallet should be scanned at the RFID mast to see if all items are present. This pallet is ready for shipping.

\subsection{Transit}

Transit parcels are sent to the regional warehouse. They are parcels which are intended directly for specific stores and must reach them within a certain time, instead of being directed to one of the departments of the warehouse. These packages are divided into dimensional and non-dimensional. The dimensional ones are thrown onto a conveyor belt, which transports them from the reception area to the UAT zone, where they are collected in transport units (euro pallets). Undersized shipments (e.g. skis, weights) are transported to the transit zone, where they should be segregated into appropriate cities. Around the zone there are pallets spread, above which the names of cities are displayed, while in the middle employees store goods that must be distributed into pallets depending on the destination. Ready-to-ship pallets with a UAT label should be checked on the RFID mat. The transit zone uses pick by voice technology. 


\subsection{High storage zone}

Non-dimensional items reach the high depot. It was divided into two divisions, consisting of several sectors. Sectors 87 and 91 receive undersized articles, articles of local suppliers and stocks of articles. Sectors 88,89 and 90 are occupied by bicycles, weights, equipment such as treadmills, stationary bicycles, etc. A high storage also differs from a low storage in that the goods are stored on high storage racks, i.e. racks with several floors. To place pallets on racks, employees use special trolleys that can lift pallets to a considerable height. Similar to the low storage, loading units (euro pallets) consist of articles with colis stickers, and a UAT label is created based on their quantity (the system counts each scanned package). Labels from the high storage can be identified by the letter "V" and from the low by the letter "G".

There are three types of supply places in the distribution centre:

- RCAS - stockpiling in the form of parcels, present in each department,

- RPAL - stockpiling in the form of pallets with packages, stored in the reception area,

- Optilog - storingg packages that do not fit in the RCAS zones.

\section{Identification of errors in the picking process}

The order is carried out simultaneously for one, two, three and even four stores. Orders are collected according to the FIFO (first in first out) principle. When all items from a given order are collected, the employee scans the labels of all items, resulting in receiving colis sticker, it means a sticker containing all the necessary information, such as: number of items, type of carrier, contractor (employee's name), time and date of printing, colis number, city where the package is intended and the store number. Such a parcel is sent by conveyor belt to the UAT zone. Before the UAT zone, the package is checked by the RFID system. In the UAT zone, the conveyor belt is divided into 10 lanes with pallets for individual cities. The conveyor is programmed in such a way that it throws packages out into lanes as intended. The exception are packages with damaged colis stickers. Then the package goes to the last lane intended for the so-called anomalies. These are packages that cannot be sent and require a solution. These packages go back to departments or are sent without flow to the customer, depending on the status of the package. Full pallets should be placed on the foliar, using a scanner to scan all colis stickers in the system, thanks to which a UAT label is obtained. The label on the item pallet should be scanned at the RFID mast to see if all items are present. This pallet is ready for shipping. Transit parcels are sent to the regional warehouse. They are parcels which are intended directly for specific stores and must reach them within a certain time, instead of being directed to one of the departments of the warehouse. These packages are divided into dimensional and non-dimensional. The dimensional ones are thrown onto a conveyor belt, 
which transports them from the reception area to the UAT zone, where they are collected in transport units (euro pallets). Undersized shipments (e.g. skis, weights) are transported to the transit zone, where they should be segregated into appropriate cities. Around the zone there are pallets spread, above which the names of cities are displayed, while in the middle employees store goods that must be distributed into pallets depending on the destination. Ready-to-ship pallets with a UAT label should be checked on the RFID mat. The transit zone uses pick by voice technology.

The quality department at the distribution centre deals with checking the correctness of both individual packaging with articles and entire loading units. In the case of individual packages, the employees' task is to check whether the quantity and type of items are consistent with the information on the label. Based on interviews with employees of the quality control department, the most common causes of errors were identified:

- taking the wrong article,

- getting the wrong number of items,

- taking an article intended for another store,

- picking up the article from the wrongly marked package - continental magazine error (CAC), in which the label was incorrectly attached. If the employee is the first to collect an article from a given package, he should check whether the article code from the order and in the package match, otherwise each subsequent person will make the same mistake.

It looks similar in the case of checking ready-to-ship loading units. When the carrier (euro pallet) receives the UAT label, it must pass quality control, which consists in counting the packages constituting the loading unit. The employee scans the UAT label and then all the labels (colis). To avoid errors, employees check that the number of packages on the carrier matches the one displayed by the system before creating the UAT label.

Based on observations while working in the UAT zone, the following causes of errors were identified:

- placing the wrong number of packages on a carrier,

- placing a package intended for another store on the carrier,

- no IT flow (packages not scanned when creating UAT).

\section{Ratio Analysis}

In order to identify areas requiring improvement in the picking process, an analysis of the following indicators was carried out: 
- timeliness of loading,

- PPM,

- productivity,

- lead time.

The data was obtained from the warehouse documentation.

\subsection{Timeliness of loading}

Timeliness of loading - percentage rate determined every month. Indicates what percentage of vehicles have been loaded according to the loading plan. This indicator is directly related to picking, because if the loading lane does not have all the items from the order, the loader is forced to delay loading. This ratio should be at least $90 \%$. Table 1 presents the results from nine months.

Table 1.

Timeliness of loading in the period from January till September

\begin{tabular}{|l|l|l|l|l|l|l|l|l|l|l|}
\hline Month & 1 & 2 & 3 & 4 & 5 & 6 & 7 & 8 & 9 & Total \\
\hline Timeliness & $72 \%$ & $85 \%$ & $90 \%$ & $96 \%$ & $95 \%$ & $97 \%$ & $96 \%$ & $97 \%$ & $96 \%$ & $91 \%$ \\
\hline
\end{tabular}

Own study.

Timeliness of loading is within the target and does not require improvement actions. The index improved significantly in the third month because a second warehouse was opened in the city of $\mathrm{Y}$, which significantly relieved the warehouse in the city of $\mathrm{X}$.

\subsection{Indicator PPM}

PPM (pieces per million) - indicates the number of errors when sending one million items. Each department is responsible for achieving the goals imposed on it, but the index is also calculated for the entire warehouse. The magazine counts PPM every week, and the set goal is a maximum of 2000 PPM. The values of the indicator are presented in Table 2.

$$
P P M=\frac{\text { number of errors }}{\text { number of checked items }} * 1000000
$$

\section{Table 2.}

$P P M$ in the first nine weeks.

\begin{tabular}{|l|c|c|c|c|c|c|c|c|c|c|}
\hline Week & 1 & 2 & 3 & 4 & 5 & 6 & 7 & 8 & 9 & Total \\
\hline PPM & 0 & 0 & 0 & 1995 & 0 & 2721 & 3006 & 9954 & 572 & 2027 \\
\hline
\end{tabular}

Own study.

The PPM indicator is not a goal, but it is close to achieving it. The values in the table above show that there are weeks when the number of errors exceeds the set limit/target. The tragic result in the eighth month is caused by mistakes of employees trained for the newly opened warehouse in the city of $Y$. 


\subsection{Productivity}

Productivity - indicates the number of packed and shipped items in one business hour. The indicator is counted every month and is calculated for employees, departments and the entire warehouse respectively. The indicator depends on the employees and working methods introduced in the distribution centre, and on its basis it is possible to determine their job performance. This indicator helps to determine the number of working hours per month needed to achieve the goals. The magazine's goal is 105 articles in one hour. The results from nine months are shown in Table 3.

Table 3.

Productivity from January till September

\begin{tabular}{|l|c|c|c|c|c|c|c|c|c|c|}
\hline Month & 1 & 2 & 3 & 4 & 5 & 6 & 7 & 8 & 9 & Total \\
\hline Productivity & 113,2 & 101,2 & 98,3 & 84,3 & 94,6 & 106,6 & 101,2 & 106,8 & 102,2 & 100,9 \\
\hline
\end{tabular}

Own study.

Analysis of the data contained in Table $\mathrm{X}$ shows that the goal was achieved only in three out of nine months.

\subsection{Lead Time}

Lead Time - indicates the average lead time. The indicator is counted weekly and covers the time from hitting items from the continental warehouse to the regional warehouse until sending the articles (from accepting to the system of articles to giving them IT flow when sending to the store). The magazine's goal lead time is processing within 47 hours.

Table 4.

Lead Time in the first 9 week

\begin{tabular}{|l|c|c|c|c|c|c|c|c|c|c|}
\hline Week & 1 & 2 & 3 & 4 & 5 & 6 & 7 & 8 & 9 & Total \\
\hline Lead time & 97 & 77,4 & 65,2 & 55 & 49,8 & 49,8 & 57,5 & 57 & 57,9 & 62,9 \\
\hline
\end{tabular}

Own study.

Analysis of the data contained in the table shows that the lead time (picking) requires improvement actions. The result is not even close to the goal, and it was not completed in any week.

A cause and effect analysis was carried out for the problem of long delivery times. The results of the analysis are presented below in the form of an Ishikawa diagram (Figure 3). 


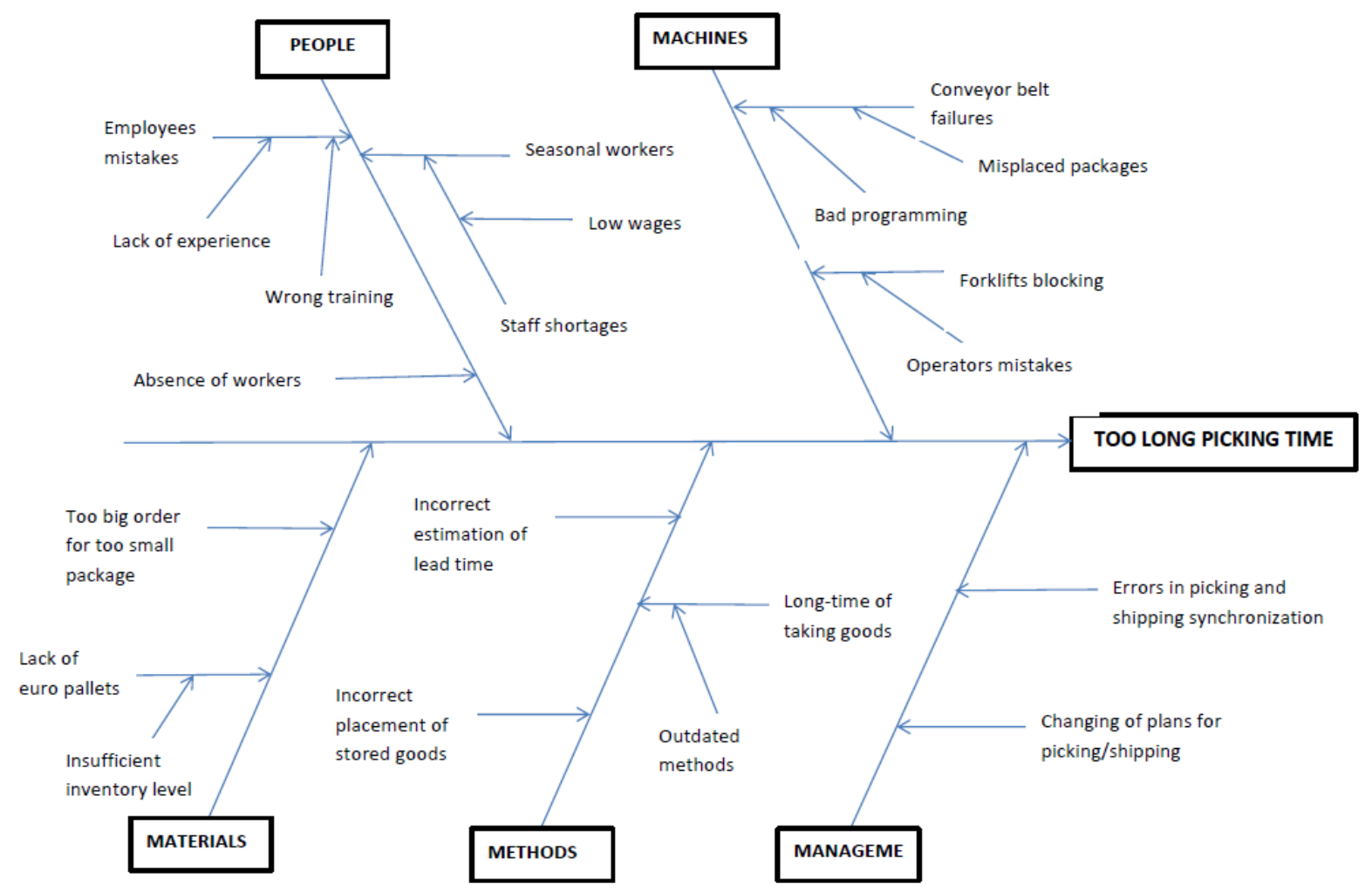

Figure 3. Ishikawa diagram. Own study.

The diagram was created on the basis of observations carried out during work in the distribution centre and on the basis of an interview with the warehouse management and employees of the low storage zone. The diagram takes into account many reasons for too long time of order picking in the warehouse, however two of them are key: it takes too much time for the employees to pick the items and improper arrangement of stored goods. Both reasons require improvement measures in the area of working methods.

\section{ABC Analysis}

The ABC analysis covered 36 groups of articles. Family groups based on the frequency of takings were arranged in descending order, then the percentage share of takings of individual groups in relation to the total was calculated. The next step was to calculate the cumulative value of the percentage share of takings. Based on the calculations obtained, it was possible to divide product groups into categories A, B and C. In the next step, the percentage share of space occupied by individual groups of items was calculated. Based on the ABC analysis, 13 groups of items were assigned to category A, which accounted for about $36 \%$ of all groups and about $80 \%$ of turnover in the distribution centre. Also 13 groups of items were assigned to category $\mathrm{B}$, where they constituted about $36 \%$ of all groups and about $15 \%$ of turnover in the distribution 
centre. The remaining 10 groups of articles were assigned to category $\mathrm{C}$ and constituted about $28 \%$ of all groups and about $5 \%$ of turnover in the distribution centre.

\section{Conclusions}

The analysis of test results, presented in earlier chapters, allowed to identify two areas requiring improvement in the picking process: productivity and organization of the storage zone. In order to improve the picking process, it was proposed to reorganize the storage zone. As a result of the reorganization, the following benefits will be achieved:

- increase in productivity,

- shortening the way of the employee while completing orders,

- shortening the picking process time.

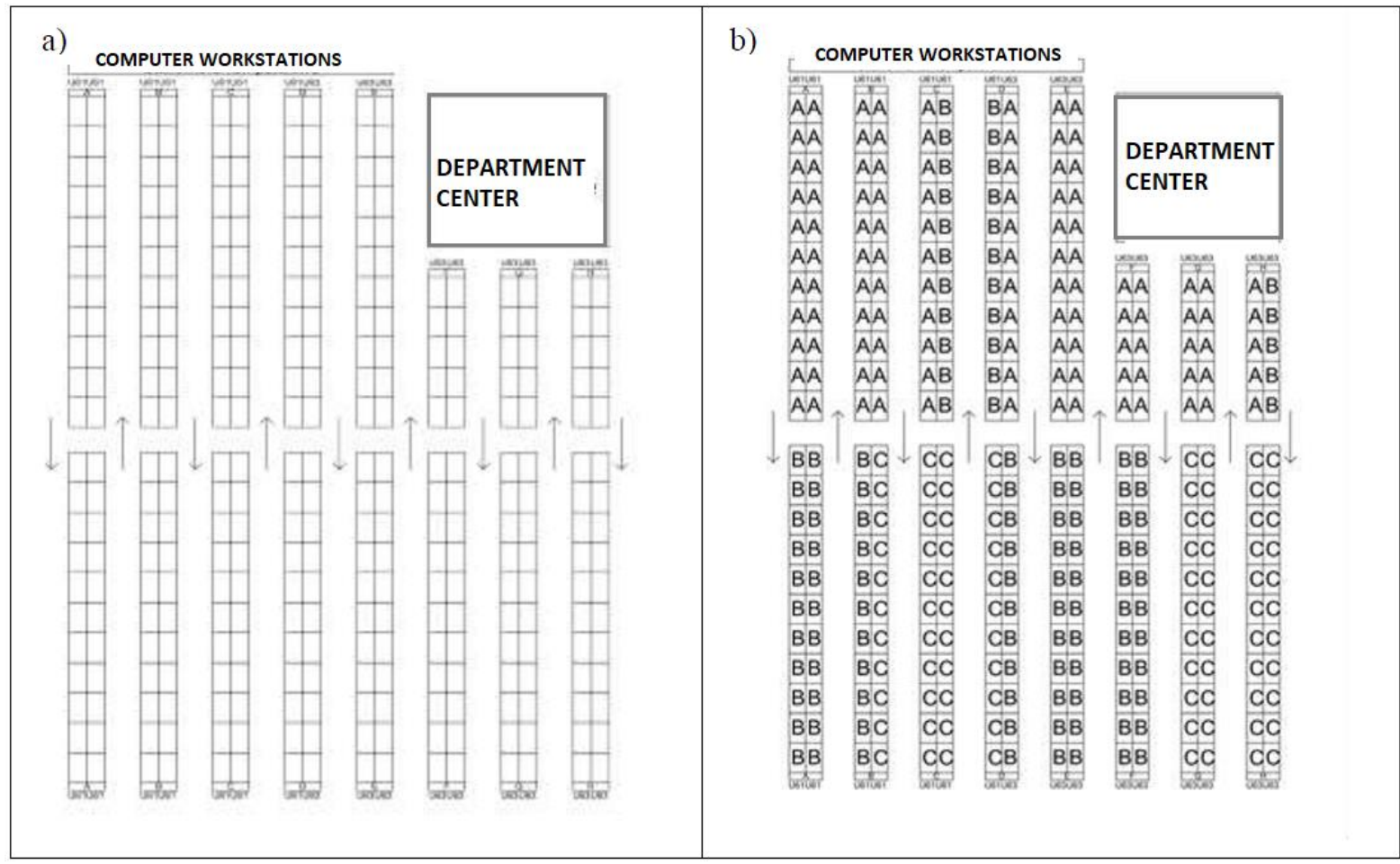

Figure 4. a) Low storage department, b) Low storage division by ABC categories. Own study.

Based on one of the low storage departments $\mathrm{ABC}$ analysis was conducted, classifying products according to the criterion of the frequency of article taken by employees. The articles were divided into groups. Based on the $\mathrm{ABC}$ analysis, individual product groups will be located in different storage places so that the way travelled by the employee during the order is as short as possible. Groups of articles from category A were located close to computer workstations, where the articles are scanned, closed in packages and then thrown onto the conveyor belt. The distribution of groups of articles by categories is shown in Fig. 4. Thanks to the proper placement of articles on the shelves, the employee during the order picking will go a much 
shorter way what results in a shorter time of order picking and less workload when completing one order. The proposed method of reorganizing the storage zone can, of course, be used in every department of low and even high storage. It should be remembered that one reorganization will not improve the work of the department for a long time, because depending on the season (the project is based on the autumn season), the frequency of taking articles changes. Tests should be carried out regularly. This method is definitely profitable for the distribution centre because it does not require any financial outlays, but only a properly trained employee responsible for the reorganization of the storage zone with the change of the season.

\section{Acknowledgements}

This paper was financed from the resources of the Silesian University of Technology, project no. BK-235/ROZ-1/2020 (13/010/BK_20/0042).

\section{References}

1. Drury, J. (1988). Towards more efficient order picking. IMM monograph, 1. UK, Cranfield: The Institute of Materials Managements.

2. Garbacz, M., and Łopuszyński, M. (2015). Optymalizacja procesu kompletacji w magazynie (cz. 2). Logistyka, 6, pp. 637-647.

3. Le Duc, T. (2005). Design and control of efficient order picking processes (Doctoral dissertation). Rotterdam: RSM Erasmus University, Rotterdam School of Economics, Erasmus Research Institute of Management. Available online https://www.erim.eur.nl/ doctoral-programme/phd-in-management/phd-tracks/detail/252-design-and-control-ofefficient-order-picking-processes/.

4. Lorenc, K., and Kaczor, G. (2012). Zwiększenie efektywności procesu kompletacji zamówień $\mathrm{w}$ wyniku optymalizacji rozmieszczenia produktów w magazynie $\mathrm{z}$ uwzględnieniem ich częstotliwości pobrań oraz gramatury. Logistyka, 5, pp. 41-45.

5. Petersen, C., Aase, G., and Heiser, D. (2004). Improving order-picking performance through the implementation of class-based storage. International Journal of Physical Distribution and Logistics Management, 34(7), pp. 534-544.

6. PN-EN 9000:2001.

7. Piller, A. (2018). Opracowanie sposobu usprawnienia procesu kompletacji zamówień magazynowych w magazynie regionalnym Decathlon CAR Gliwice (Engineering Project). Zabrze: Silesian University of Technology, Faculty of Organization and Management. 
8. Ratkiewicz, A. (2011). Efektywność procesu kompletacji. Logistyka, 4, pp. 794-800.

9. Sabo-Zielonka, A., and Tarczyński, G. (2014). Porównanie czasów kompletacji zamówień dla różnych sposobów wyznaczania trasy magazynierów na przykładzie dużego centrum logistycznego. Ekonometria, 2(44), pp. 62-81, doi: 10.15611/ekt.2014.2.06.

10. Szada-Borzyszkowska, M., and Szada-Borzyszkowski, W. (2017). Usprawnienie trasy kompletacji zamówienia w magazynie części do montażu pojazdów samochodowych. Autobusy, 7-8, pp. 271-274.

11. Tarczyński, G. (2013). Wielokryterialna ocena procesu kompletacji towarów w magazynie. Katowice: Wydawnictwo Uniwersytetu Ekonomicznego, p. 222. 